\title{
Effect of Spirulina Supplementation on Systolic and Diastolic Blood Pressure: Systematic Review and Meta-Analysis of Randomized Controlled Trials
}

\author{
Piotr Machowiec*(D), Gabriela Ręka (D), Marcela Maksymowicz D, Halina Piecewicz-Szczęsna and Agata Smoleń (DD \\ Department of Epidemiology and Clinical Research Methodology, Medical University of Lublin, \\ 20-080 Lublin, Poland; gabrysia.reka@gmail.com (G.R.); marcela.maksymowicz@gmail.com (M.M.); \\ halpiec@gmail.com (H.P.-S.); agata.smolen@umlub.pl (A.S.) \\ * Correspondence: h.piecewicz@umlub.pl or piotr.machowiec1997@gmail.com
}

check for

updates

Citation: Machowiec, P.; Rẹka, G.; Maksymowicz, M.; Piecewicz-

Szczęsna, H.; Smoleń, A. Effect of Spirulina Supplementation on Systolic and Diastolic Blood Pressure: Systematic Review and MetaAnalysis of Randomized Controlled Trials. Nutrients 2021, 13, 3054. https://doi.org/10.3390/nu13093054

Academic Editor: Jaakko Tuomilehto

Received: 26 July 2021

Accepted: 29 August 2021

Published: 31 August 2021

Publisher's Note: MDPI stays neutral with regard to jurisdictional claims in published maps and institutional affiliations.

Copyright: (c) 2021 by the authors. Licensee MDPI, Basel, Switzerland. This article is an open access article distributed under the terms and conditions of the Creative Commons Attribution (CC BY) license (https:// creativecommons.org/licenses/by/ $4.0 /)$.

\begin{abstract}
Spirulina is a microalga that presents various important pro-health properties, for instance lowering blood pressure in the research. The study aims to appraise the efficacy of Spirulina administration on systolic (SBP) and diastolic blood pressure (DBP). Randomized controlled trials (RCTs) were retrieved by a systematic search of PubMed, Web of Science, and the Cochrane Library databases from inception to June 2021 according to a standardized protocol. The effect size of each study was counted from mean and standard deviation before and after the intervention and shown as Un-standardized mean difference and 95\% confidence interval. Sensitivity analyses were performed. Meta-analysis on 5 RCTs with 230 subjects was eligible. The amount of Spirulina ranged from 1 to $8 \mathrm{~g}$ per day, and intervention durations ranged from 2 to 12 weeks. Data analysis indicated that Spirulina supplementation led to a significant lowering of SBP (Mean Difference (MD): $-4.59 \mathrm{mmHg}, 95 \%$ Confidence Interval (CI): -8.20 to -0.99 , I square statistic $\left(\mathrm{I}^{2}\right)=65 \%$ ) and significant lowering of DBP (MD: $-7.02 \mathrm{mmHg}$, CI: -8.86 to $-5.18, \mathrm{I}^{2}=11 \%$ ), particularly in a subgroup of hypertensive patients. Spirulina administration might have a supportive effect on the prevention and treatment of hypertension. More exact randomized controlled trials are needed to clarify the effect of Spirulina supplementation on blood pressure.
\end{abstract}

Keywords: Spirulina; blood pressure; diastolic pressure; systolic pressure; hypertension; food supplements; meta-analysis

\section{Introduction}

Arterial hypertension is the crucial independent risk factor in cardiovascular diseases for developed countries, characterized by an increasing prevalence in recent years $[1,2]$. Despite significant advancement in perception, diagnosis, and therapy of hypertension, it is underlined that blood pressure control is insufficient in less than half of the hypertensive patients and it poses a challenge for further patients' management [2]. The most common method of treatment of hypertension is drug therapy. Nevertheless, one of the difficulties with decreasing blood pressure values is that monotherapy is often inadequate and that is why combination therapy may be considered in some cases [3,4], especially in elderly patients. Alternatively, natural medical products are frequently used as adjunctive therapy to improve long-term outcomes in patients with arterial hypertension and to reduce the number of antihypertensive drugs that are taken. Thus, it may potentially exclude the side effects concerned with combination therapy use [5].

The intake of microalgae has been popularized for centuries and for the sake of their nutritional value and properties, its intake is recommended by organizations, such as WHO (World Health Organization) and FAO (The Food and Agriculture Organization) [6,7]. Microalgae contain a variety of biologically valuable substances including proteins, polyunsaturated fatty acids, amino acids, antioxidants, pigments, minerals, and vitamins [7]. 
Spirulina, a microscopic and filamentous cyanobacterium is considered a sustainable and eco-friendly microalga, playing an increasing role in alternative medicine [8].

Spirulina presents various important pro-health properties according to experimental studies and human research. Antioxidant, anti-inflammatory, and immunomodulatory activities of Spirulina were investigated in experimental studies on animals [9-12]. Hypoglycemic and hypolipidemic activities were described in human research [9,13]. According to clinical studies, the antioxidant activity of Spirulina might be a potential treatment for chronic obstructive pulmonary disease and might improve motor development among infants [10,14].

The effect of Spirulina intake on blood pressure is considered in some human randomized clinical trials. However, the results are not completely decisive and they should be deepened. A few studies indicated that Spirulina significantly changes (lowers) only the systolic blood pressure (SBP) $[15,16]$ or only the diastolic blood pressure (DBP) [17]. Two studies reported that there were no statistically significant differences between the experimental and control group regarding systolic and diastolic blood pressure [18,19]. In this meta-analysis, we evaluated the effectiveness of Spirulina supplementation on systolic and diastolic blood pressure to elucidate the subject. According to the PICOS (Participants, Intervention, Comparison, Outcomes, Study design) statement, our meta-analysis aims to find an answer to the question does the oral use of Spirulina in a daily dose from 1 to $8 \mathrm{~g}$ and more for 2,8 , or 12 weeks in adult patients with co-existing diseases reduce systolic and diastolic blood pressure.

\section{Materials and Methods}

\subsection{Review Design and Search Strategy}

The Preferred Reporting Items for Systematic Reviews and Meta-Analyses (PRISMA) guideline was complied with to perform a meta-analysis and report the results [20]. Three databases including PubMed, Web of Science, and the Cochrane Library from inception to June 2021 were systematically searched to find accurate studies. The search terms for the PubMed database were: (Spirulina) AND (intervention studies [MESH] OR intervention [tiab] OR controlled trial [tiab] OR random [tiab] OR randomised [tiab] OR randomized [tiab] OR randomly [tiab] OR assignment [tiab] OR clinical trial [All fields] OR trial [All field]) and for searching the Cochrane Library: Spirulina AND (clinical trial OR trial OR clinical study). The following phrases were used to search Web of Science: (Spirulina) AND (intervention studies OR intervention OR controlled trial OR random OR randomised OR randomized OR randomly OR assignment OR clinical trial OR trial). Manual searching of retrieved studies was performed not to miss randomized controlled trials (RCTs). Two authors (GR \& MM) independently explored databases and carefully evaluated the articles. Inconsistent issues were resolved by discussion with the other two authors (PM \& HPS).

\subsection{Study Selection}

Typical inclusion criteria used for the selection of all relevant articles were as followed: (i) the parallel-group or cross-over RCTs in which Spirulina was administered in the intervention group, (ii) RCTs used a concurrent control group for the Spirulina supplementation group, and the difference between intervention and control group was Spirulina, (iii) RCTs provided sufficient data on the baseline and final levels of blood pressure, both SBP and DBP in Spirulina and control group. The search was restricted to English-language publications (iv). Non-randomized, non-control, experimental studies and studies with a lack of adequate data on SBP and DBP values before and after Spirulina supplementation required for meta-analysis were excluded. Publications without clear information on the selection of patients and unambiguous method of carrying out randomization and blinding process were rejected, which could have contributed to overestimating the effect of the intervention. 


\subsection{Extraction and Qualification of the Data}

For each selected RCTs, the following data were extracted: first author' identification, publication year, study design, study location, number of participants in Spirulina and control groups, gender and mean age of subjects, participants' health status, daily dose, intervention duration, and outcomes of interest (SDB and DBP levels).

To evaluate the quality of included RCTs, the Jadad scale was used [21]. The scores $\geq 3$ were classified as high-quality trials, whereas scores $<3$ as low-quality trials (possible score ranges between 0 and 5) [22]. Two authors (PM \& GR) independently classified the included studies according to the Jadad scale. To make a consensus, final scores were consulted with the authors.

\subsection{Statistical Methods}

The effect size of each study was counted from the mean and standard deviation (SD) of the results before and after the intervention, and subsequently shown as Un-standardized mean difference and $95 \%$ confidence interval $(\mathrm{CI})$. To extract one mean and one standard deviation in the studies, in which mean $\pm \mathrm{SD}$ were divided into females and males, the certain transformations were used based on Cochrane's formulae for combining groups (Table 1). Standard deviations (SDs) of the mean difference between pre-treatment and posttreatment values in the intervention and control groups were calculated using the following formula: $\mathrm{SD}=$ square root $\left[\left(\mathrm{SD}_{\text {pre-treatment }}\right)^{2}+\left(\mathrm{SD}_{\text {post-treatment }}\right)^{2}-\left(2 \mathrm{R} \times \mathrm{SD}_{\text {pre-treatment }} \times\right.\right.$ $\left.\mathrm{SD}_{\text {post-treatment }}\right)$, imputing a correlation coefficient as described in Cochrane recommendations (Table 1). In studies where the standard error of the mean (SEM) was reported, SD was calculated as follows: SD $=\mathrm{SEM} \times$ sqrt (n), where $\mathrm{n}$ is the number of participants. On account of the fact that selected RCTs were carried out in different settings including the type of Spirulina supplement used, Spirulina dose, duration of Spirulina supplementation, and demographic characteristics of in-dividual trials, random effects model was used to calculate the overall effect from effect sizes $[23,24]$. The effect of heterogeneity was quantified by I-squared $\left(\mathrm{I}^{2}\right)$ statistic, ranging from 0 to $100 \%$ as $\mathrm{I}^{2}>60 \%$ refers to considerable heterogeneity [25]. To find the potential sources of between-study heterogeneity, we carried out a pre-planned subgroup analysis based on dose of intervention, duration of Spirulina intake and baseline blood pressure. In case of significant heterogeneity random effect analysis was performed. Sensitivity analysis was carried out to explore the inference of each study on overall effect. Potential publication bias was not assessed due to an insufficient number of studies $(n<10)$, so the power of the tests is too low to differentiate chance from real asymmetry [26]. Review Manager software version 5.4.1 (Cochrane IMS, Oxford, UK) was employed to perform statistical analyses and draw the forest plots. $p$ values $\leq 0.05$ was considered as statistically significant.

Table 1. Formulae used for data extraction for continuous outcomes.

\begin{tabular}{|c|c|}
\hline Name & Formulae \\
\hline Formula for combining groups-mean & Mean $=\mathrm{N}_{1} \mathrm{M}_{1}+\mathrm{N}_{2} \mathrm{M}_{2} / \mathrm{N}_{1}+\mathrm{N}_{2}$ \\
\hline Formula for combining groups-SD & $\begin{array}{c}\text { SD = square root }\left[\left(\mathrm{N}_{1}-1\right) \mathrm{SD}_{1}^{2}+\left(\mathrm{N}_{2}-1\right) \mathrm{SD}_{2}^{2}+\right. \\
\left.\left(\mathrm{N}_{1} \mathrm{~N}_{2} / \mathrm{N}_{1}+\mathrm{N}_{2}\right) \times\left(\mathrm{M}_{1}^{2}+\mathrm{M}_{2}^{2}-2 \mathrm{M}_{1} \mathrm{M}_{2}\right)\right] / \\
\left(\mathrm{N}_{1}+\mathrm{N}_{2}-1\right)\end{array}$ \\
\hline $\begin{array}{l}\text { Formula for imputing } \\
\text { correlation coefficient }\end{array}$ & Corr $=\left(\mathrm{SD}_{\mathrm{E}}^{2}+\mathrm{SD}_{\mathrm{C}}^{2}-\mathrm{SD}_{\text {diff }}^{2}\right) /\left(2 \times \mathrm{SD}_{\mathrm{E}} \times \mathrm{SD}_{\mathrm{C}}\right)$ \\
\hline
\end{tabular}

$\mathrm{N}$-sample size, $\mathrm{M}$ - mean, $\mathrm{SD}_{\mathrm{E}}$ - standard deviation of experimental intervention, $\mathrm{SD}_{\mathrm{C}}$-standard deviation of control intervention, $\mathrm{SD}_{\text {diff }}$-difference between experimental and control interventions' SD.

\section{Results}

\subsection{Selection and Identification of Studies}

From database searching, 774 records were retrieved in our systematic search. Of these, 233 duplicated records were excluded. Among the remaining, 533 were removed. 
Reasons for exclusion present as follows: 441 items irrelevant to the topic, 52 trial protocols, 6 animal/non-human studies, 20 review articles and other non-RCTs, and 14 due to lack of data on systolic/diastolic blood pressure values before or after Spirulina supplementation. The studies containing only the values of SBP or DBP were accepted solely when comprising pre- and post Spirulina supplementation blood pressure values. The next 3 records were rejected because they did not report the results. Finally, 5 studies were available for the main analysis. A flow diagram showing the accurate study selection and identification process is presented in Figure 1.
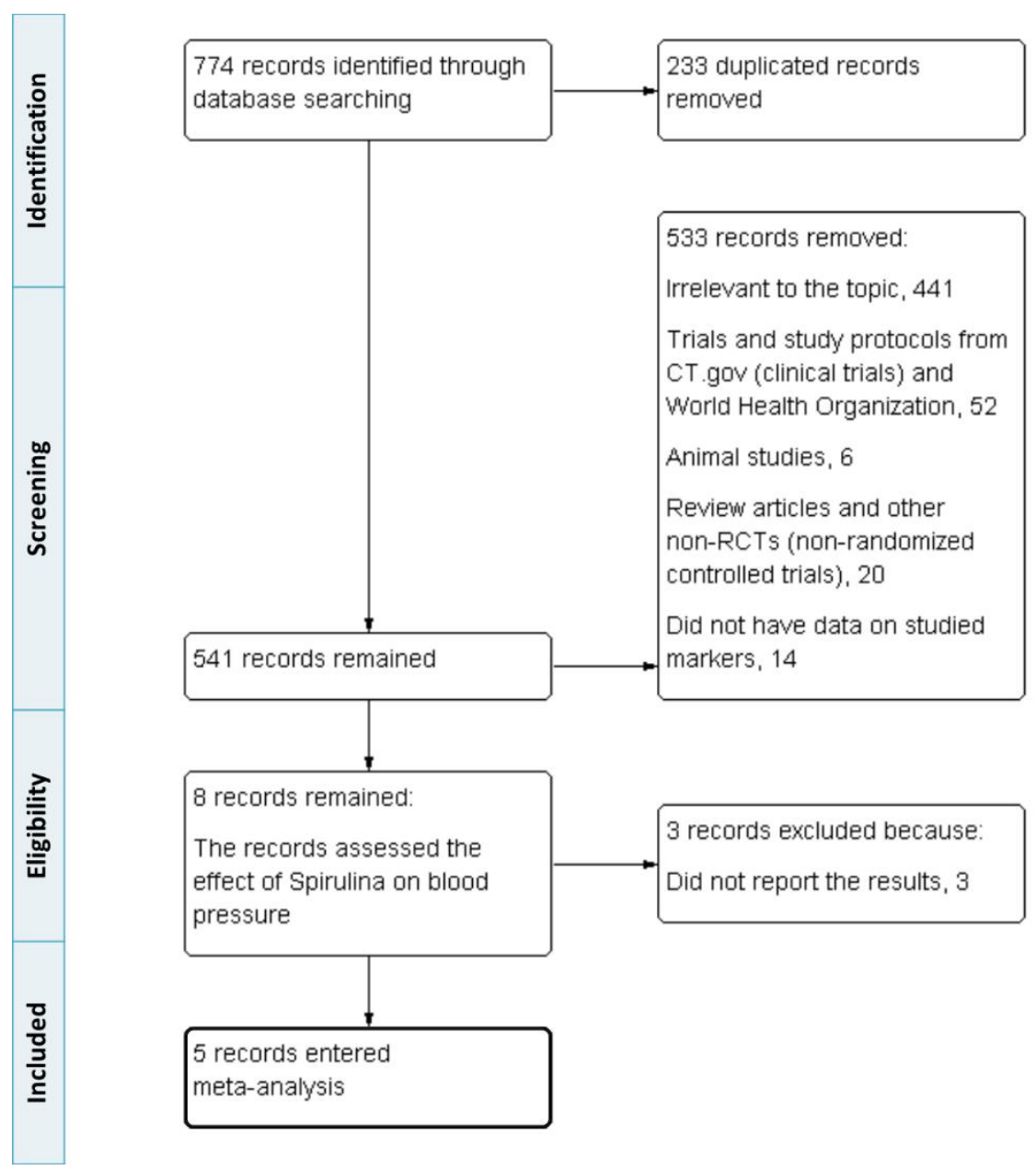

Figure 1. Preferred Reporting Items for Systematic Reviews and Meta-analyses (PRISMA) flow diagram of study identification, inclusion, and exclusion.

\subsection{Characteristics of Studies}

In total, 5 randomized controlled trials with 230 subjects for SBP and 4 RTCs with 214 subjects for DBP were enrolled in meta-analysis [15-19]. PICOS criteria for inclusion and exclusion of studies are available in Table 2. All studies were published between 2008 and 2021 and were conducted in five different countries, including Mexico, Poland, South Korea, the USA, and Iran (Table 3). All RCTs were designed as parallel-group studies. Four of them used the placebo as the control and one trial used no intervention as the control. The dose of Spirulina ranged from 1 to $8 \mathrm{~g}$ per day. The intervention duration was 3 months (12 weeks) for three studies, 8 weeks for one study, and 2 weeks for another. All patients were adults and they suffered from co-existing diseases, for instance, hypertension, diabetes mellitus type 2 , chronic joint pain, and ulcerative colitis (Table 4). 
Table 2. Participants, Intervention, Comparison, Outcomes and Study design (PICOS) criteria for inclusion and exclusion of studies.

\begin{tabular}{|c|c|}
\hline Parameter & Description \\
\hline Participants & $\begin{array}{l}\text { Adults with arterial hypertension, diabetes mellitus type 2, Body Mass Index } \\
\qquad(\mathrm{BMI})<35 \text { and chronic joint pain, or ulcerative colitis }\end{array}$ \\
\hline Interventions & $\begin{array}{l}\text { Oral daily supplementation of Spirulina }(1 \mathrm{~g}, 2 \mathrm{~g}, 2.3 \mathrm{~g}, 4.5 \mathrm{~g}, 8 \mathrm{~g}) \text { for } 2,8 \text {, or } \\
\qquad 12 \text { weeks }\end{array}$ \\
\hline Comparison & $\begin{array}{l}\text { Oral daily placebo (pure microcrystalline cellulose or not specified) or no } \\
\text { intervention }\end{array}$ \\
\hline Outcomes & Decrease of SBP and DBP \\
\hline Study design & Parallel RCTs were included in the meta-analysis \\
\hline
\end{tabular}

Table 3. Detailed parameters of systolic blood pressure (SBP) and diastolic blood pressure (DBP) from the included randomized controlled trials (RCTs).

\begin{tabular}{|c|c|c|c|c|}
\hline Reference & No. of Subjects & $\begin{array}{c}\text { Outcomes Studied } \\
\text { before and after } \\
\text { Supplementation }\end{array}$ & Spirulina Group & $\begin{array}{c}\text { Placebo/ Non-Spirulina } \\
\text { Group }\end{array}$ \\
\hline $\begin{array}{l}\text { Martínez-Sámano et al., } \\
2018 \text { [15] }\end{array}$ & $\begin{array}{c}n=8 \text { Spirulina } \\
n=8 \text { placebo }\end{array}$ & $\begin{array}{l}\text { SBP }(\mathrm{mmHg}) \text { before } \\
\text { SBP }(\mathrm{mmHg}) \text { after } \\
\text { DBP }(\mathrm{mmHg}) \text { before } \\
\text { DBP }(\mathrm{mmHg}) \text { after }\end{array}$ & $\begin{array}{c}140.38 \pm 9.04 \\
126.50 \pm 5.53 \\
83.75 \pm 5.31 \\
-\end{array}$ & $\begin{array}{c}140.75 \pm 7.03 \\
140.00 \pm 6.05 \\
84.25 \pm 5.28 \\
-\end{array}$ \\
\hline Miczke et al., 2016 [16] & $\begin{array}{c}n=40 \text { Spirulina } \\
n=40 \text { placebo }\end{array}$ & $\begin{array}{l}\text { SBP }(\mathrm{mmHg}) \text { before } \\
\text { SBP }(\mathrm{mmHg}) \text { after } \\
\text { DBP }(\mathrm{mmHg}) \text { before } \\
\text { DBP }(\mathrm{mmHg}) \text { after }\end{array}$ & $\begin{array}{l}149 \pm 7 \\
143 \pm 9 \\
84 \pm 9 \\
79 \pm 9\end{array}$ & $\begin{array}{c}150 \pm 7 \\
151 \pm 9 \\
85 \pm 9 \\
86 \pm 7\end{array}$ \\
\hline Lee et al., 2008 [17] & $\begin{array}{c}n=19 \text { Spirulina } \\
n=18 \text { non-Spirulina }\end{array}$ & $\begin{array}{l}\text { SBP }(\mathrm{mmHg}) \text { before } \\
\text { SBP }(\mathrm{mmHg}) \text { after } \\
\text { DBP }(\mathrm{mmHg}) \text { before } \\
\text { DBP }(\mathrm{mmHg}) \text { after }\end{array}$ & $\begin{array}{l}130.7 \pm 3.8 \\
129.4 \pm 2.7 \\
84.0 \pm 2.1 \\
79.8 \pm 2.1\end{array}$ & $\begin{array}{l}131.8 \pm 4.0 \\
133.4 \pm 4.5 \\
80.1 \pm 2.5 \\
83.5 \pm 2.7\end{array}$ \\
\hline Jensen et al., 2016 [18] & $\begin{array}{c}n=12 \text { Spirulina }(\text { female } \mathrm{F} \\
=10, \text { male } \mathrm{M}=2) \\
n=12 \text { placebo }(\mathrm{F}=9, \\
\mathrm{M}=3)\end{array}$ & $\begin{array}{l}\text { SBP }(\mathrm{mmHg}) \text { before } \\
\text { SBP }(\mathrm{mmHg}) \text { after } \\
\text { DBP }(\mathrm{mmHg}) \text { before } \\
\text { DBP }(\mathrm{mmHg}) \text { after }\end{array}$ & $\begin{array}{c}\text { F } 120.8 \pm 15.3 \\
\text { M } 113.5 \pm 6.4 \\
\text { F } 120 \pm 15.8 \\
\text { M } 114 \pm 2.8 \\
\text { F } 75.5 \pm 12 \\
\text { M 75 } \pm 5.7 \\
\text { F } 73.3 \pm 11.6 \\
\text { M } 73.5 \pm 6.4 \\
\end{array}$ & $\begin{array}{c}\text { F } 112.7 \pm 8.9 \\
\text { M } 131.7 \pm 5.5 \\
\text { F } 111.3 \pm 9.9 \\
\text { M } 127.7 \pm 9.0 \\
\text { F } 70.8 \pm 9.1 \\
\text { M } 75 \pm 7 \\
\text { F } 70.2 \pm 9.6 \\
\text { M } 75.3 \pm 7.6\end{array}$ \\
\hline Moradi et al., 2021 [19] & $\begin{array}{c}n=36 \text { Spirulina } \\
n=37 \text { placebo }\end{array}$ & $\begin{array}{l}\text { SBP }(\mathrm{mmHg}) \text { before } \\
\text { SBP }(\mathrm{mmHg}) \text { after } \\
\text { DBP }(\mathrm{mmHg}) \text { before } \\
\text { DBP }(\mathrm{mmHg}) \text { after }\end{array}$ & $\begin{array}{l}118.7 \pm 9.0 \\
118.3 \pm 6.6 \\
80.4 \pm 5.6 \\
80.6 \pm 5.3\end{array}$ & $\begin{array}{c}117.8 \pm 16.6 \\
118.6 \pm 4.8 \\
79.7 \pm 11.6 \\
80.0 \pm 4.7\end{array}$ \\
\hline
\end{tabular}

According to Jadad scores [21], 1 study [15] was categorized as a low-quality study (score $<3$ ) and 4 studies [16-19] as high-quality studies (score $\geq 3$ ).

Effect sizes for the impact of Spirulina supplementation on systolic blood pressure were robust in the sensitivity analysis. It suggests that desertion of each RCT had no significant effect on the results. Also, sensitivity analysis for diastolic blood pressure was conducted, indicating primarily that dropping one study influenced overall effect significantly. However, after the exclusion of one trial, sensitivity analysis showed the same results as in the case of SBP.

Two authors (HPS \& AS) separately assessed the methodological quality of RCTs through Cochrane Collaboration's tool which includes six domains (Figure 2). Each domain was classified to the following categories: low, high, and unclear risk of bias $(1,0$, or?). Overall quality of each study was considered as good, fair, and weak: $>2,=2$, and $<2$, respectively. After evaluating the quality of included studies, the quality score of 4 studies were classified as good quality and 1 as fair quality. 
Table 4. Characteristics of included randomized controlled trials (RCTs).

\begin{tabular}{|c|c|c|c|c|c|c|c|c|c|}
\hline Reference & Location & $\begin{array}{l}\text { Quality } \\
\text { Score }\end{array}$ & $\begin{array}{l}\text { Study } \\
\text { Design }\end{array}$ & $\begin{array}{l}\text { No. of } \\
\text { Subjects }\end{array}$ & $\begin{array}{l}\text { Health } \\
\text { Status }\end{array}$ & $\begin{array}{l}\text { Intervention } \\
\text { Duration }\end{array}$ & $\begin{array}{l}\text { Spirulina } \\
\text { Group }\end{array}$ & Control Group & $\begin{array}{c}\text { Outcomes } \\
\text { Studied }\end{array}$ \\
\hline $\begin{array}{c}\text { Martinez- } \\
\text { Samano } \\
\text { et al., 2018 } \\
{[15]}\end{array}$ & Mexico & 2 & Parallel & 16 & $\begin{array}{l}\text { Systemic } \\
\text { arterial hy- } \\
\text { pertension }\end{array}$ & 12 weeks & $\begin{array}{c}4.5 \text { g per day of } \\
\text { Spirulina } \\
\text { maxima }\end{array}$ & Placebo & SBP, DBP \\
\hline $\begin{array}{l}\text { Miczke et al., } \\
2016 \text { [16] }\end{array}$ & Poland & 4 & Parallel & 80 & $\begin{array}{l}\text { Systemic } \\
\text { arterial hy- } \\
\text { pertension }\end{array}$ & 12 weeks & $\begin{array}{l}2 \text { g per day of } \\
\text { Hawaiian } \\
\text { Spirulina } \\
\text { maxima }\end{array}$ & $\begin{array}{c}\text { Placebo } \\
\text { consisted of } \\
\text { pure microcrys- } \\
\text { talline } \\
\text { cellulose }\end{array}$ & SBP, DBP \\
\hline $\begin{array}{l}\text { Lee et al., } \\
2008 \text { [17] }\end{array}$ & South Korea & 3 & Parallel & 37 & $\begin{array}{c}\text { Diabetes } \\
\text { mellitus } \\
\text { type } 2\end{array}$ & 12 weeks & $\begin{array}{l}8 \mathrm{~g} \text { per day of } \\
\text { of freeze-dried } \\
\text { Spirulina }\end{array}$ & $\begin{array}{c}\text { Received } \\
\text { nothing } \\
\text { (control group } \\
\text { was instructed } \\
\text { not to take any } \\
\text { functional } \\
\text { foods or } \\
\text { supplements) }\end{array}$ & SBP, DBP \\
\hline $\begin{array}{l}\text { Jensen et al., } \\
2016 \text { [18] }\end{array}$ & USA & 3 & Parallel & 24 & $\begin{array}{c}\text { Adults } 25-65 \\
\text { years of age } \\
\text { with } \\
\text { BMI }<35 \\
\text { and chronic } \\
\text { pain related } \\
\text { to specific } \\
\text { joint(s) for } \\
>6 \text { months }\end{array}$ & 2 weeks & $\begin{array}{l}2.3 \mathrm{~g} \text { per day of } \\
\text { of } \\
\text { phycocyanin- } \\
\text { enriched } \\
\text { aqueous } \\
\text { extract from } \\
\text { Arthrospira } \\
\text { (Spirulina) } \\
\text { platensis }\end{array}$ & Placebo & SBP, DBP \\
\hline $\begin{array}{l}\text { Moradi et al., } \\
2021 \text { [19] }\end{array}$ & Iran & 5 & Parallel & 73 & $\begin{array}{l}\text { Ulcerative } \\
\text { colitis }\end{array}$ & 8 weeks & 1 g per day of & Placebo & SBP, DBP \\
\hline
\end{tabular}

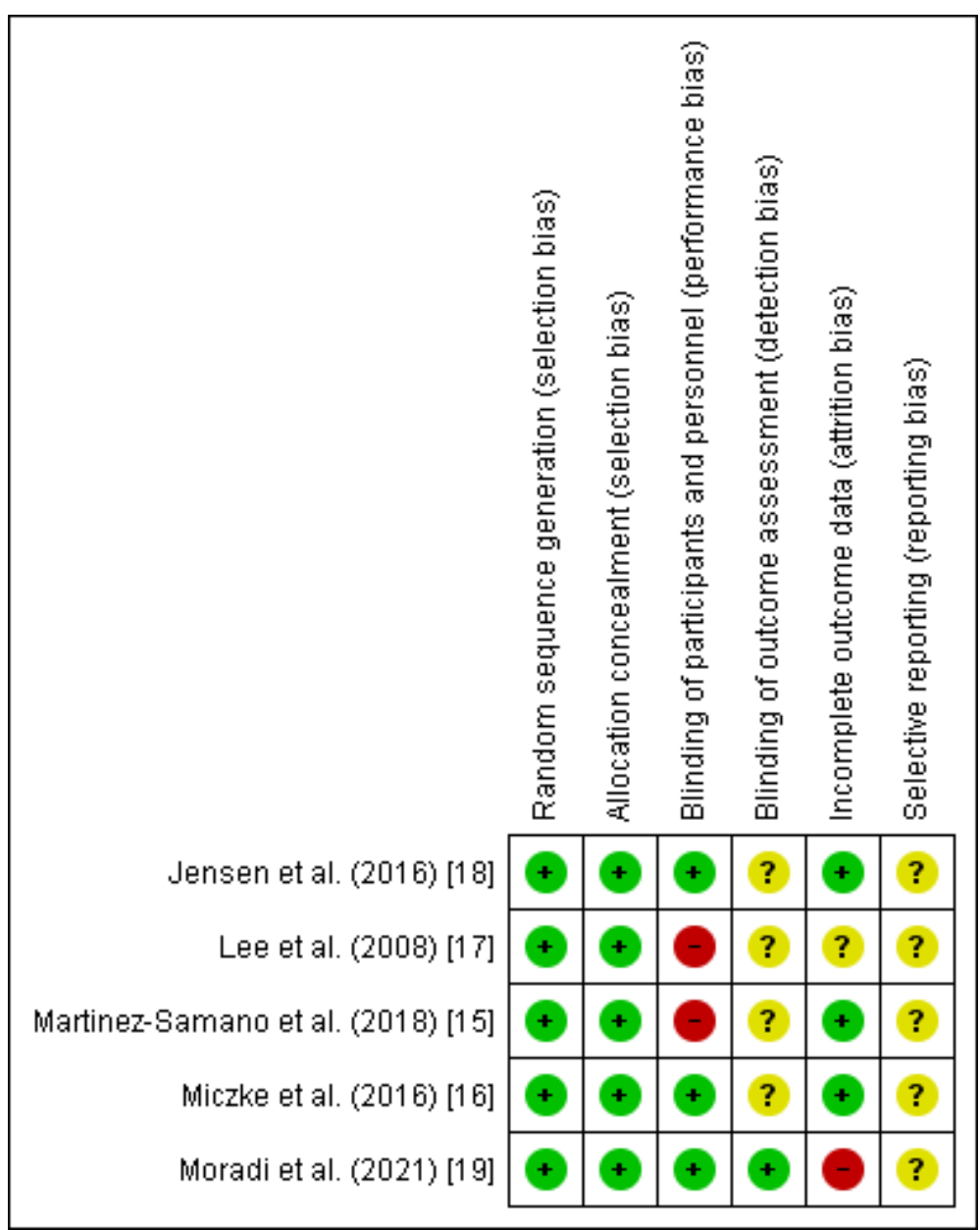

Figure 2. Risk of bias assessment for included randomized controlled trials (RCTs) [15-19]. 


\subsection{Effect of Spirulina on Systolic Blood Pressure}

The effect of the Spirulina administration on systolic blood pressure was assessed based on 5 RCTs. Pooled analysis revealed that Spirulina intake led to a significant lowering of SBP (MD: $-4.59 \mathrm{mmHg}, 95 \% \mathrm{CI}:-8.20$ to $-0.99, \mathrm{I}^{2}=65 \%$ ). There was a significant between-study heterogeneity $\left(\mathrm{I}^{2}=65 \% ; p=0.02\right)$ in which dose of Spirulina, duration of Spirulina intake, and baseline blood pressure were identified as sources of heterogeneity in the subgroup analysis (Figure 3). As shown in Figure 4, subgroup analysis based on a dose of supplementation indicated no difference between low-dose $-\leq 2 \mathrm{~g}$ (MD: $-4.17 \mathrm{mmHg}$, 95\% CI: -9.85 to 1.52 ) or high-dose $\longrightarrow 2$ g (MD: $-5.17 \mathrm{mmHg}$, 95\% CI: -12.60 to 2.26 ) supplementation. Furthermore, subgroup analysis based on " $\geq 12$ weeks" or " $<12$ weeks" duration of Spirulina intake did not show any difference between subgroups (MD: -6.67 $\mathrm{mmHg}$, 95\% CI: -11.53 to -1.81 vs. MD: $-0.87 \mathrm{mmHg}$, 95\% CI: -4.77 to 3.03 ) (Figure 5). The only significant difference was noticed in subgroup analysis based on baseline blood pressure. It indicated that Spirulina supplementation resulted in greater SBP lowering in the "hypertensive" subgroup (MD: $-9.18 \mathrm{mmHg}, 95 \% \mathrm{CI}:-14.93$ to -3.43 ) compared with the "normotensive" subgroup (MD: $-2.26 \mathrm{mmHg}, 95 \% \mathrm{CI}:-4.44$ to -0.08 ) (Figure 6).

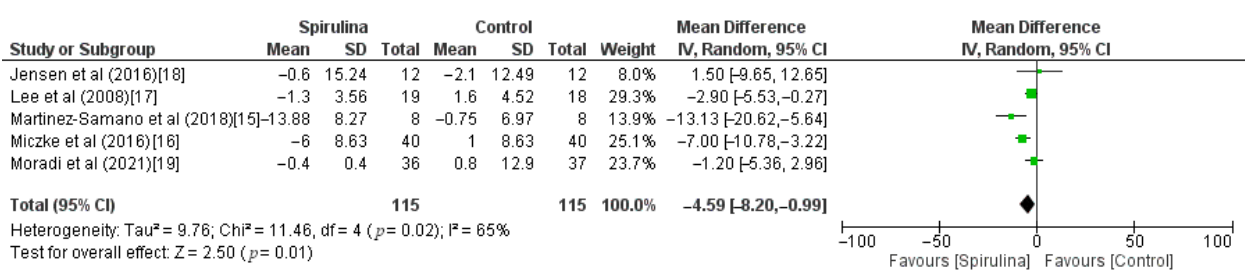

Figure 3. Effect of Spirulina supplementation on systolic blood pressure (SBP) compared with the control group [15-19].

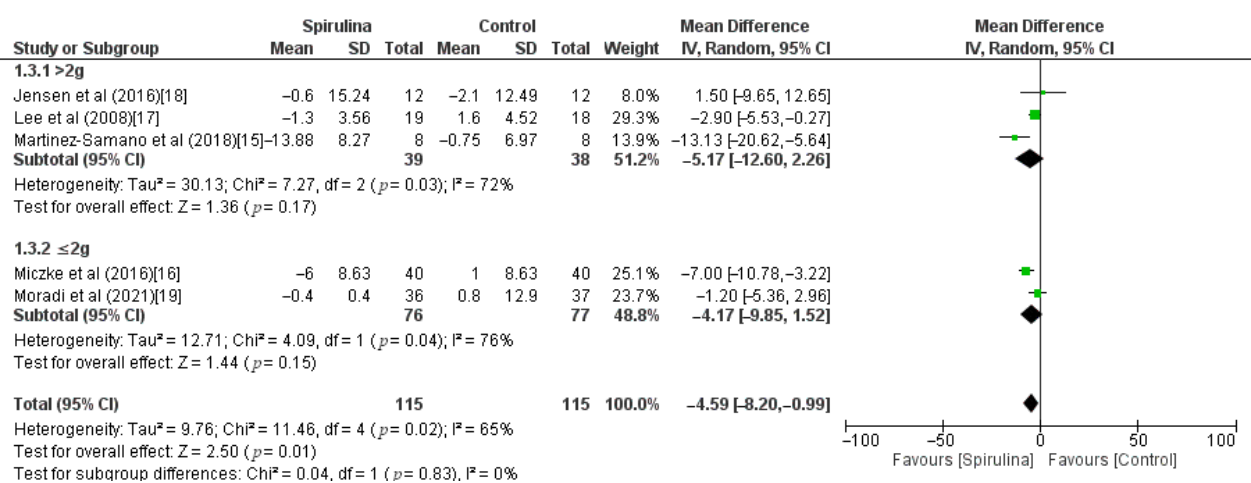

Figure 4. Effect of Spirulina supplementation on systolic blood pressure (SBP) compared with the control group stratified by Spirulina dosage [15-19].

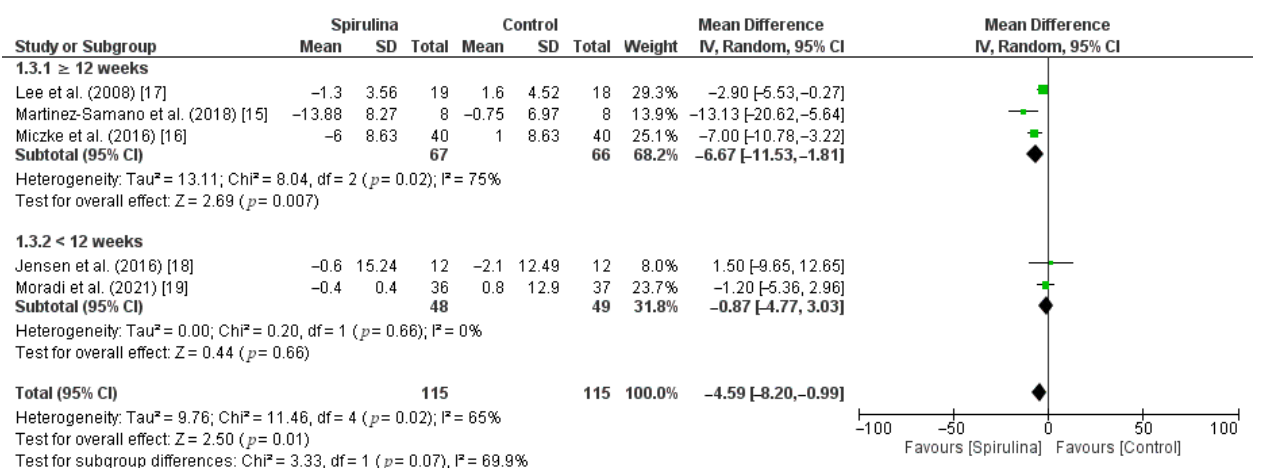

Figure 5. Effect of Spirulina supplementation on systolic blood pressure (SBP) compared with the control group stratified by duration of Spirulina intake [15-19]. 


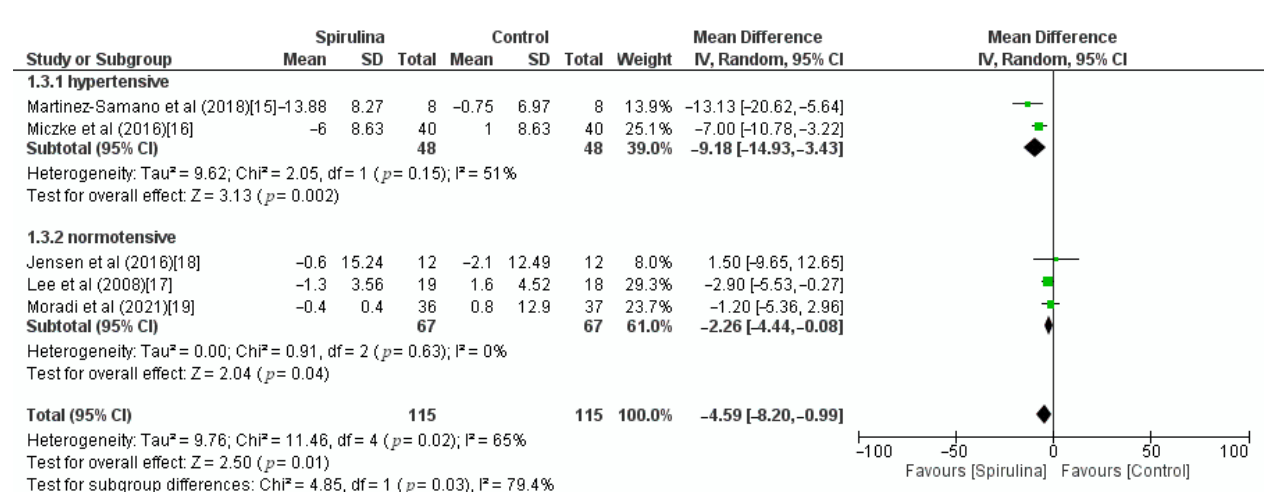

Figure 6. Effect of Spirulina supplementation on systolic blood pressure (SBP) compared with the control group stratified by baseline blood pressure [15-19].

\subsection{Effect of Spirulina on Diastolic Blood Pressure}

Pooled analysis of 4 RCTs showed that Spirulina intake significantly lowered DBP (MD: $-4.29 \mathrm{mmHg}$, CI: -8.43 to $-0.14, \mathrm{I}^{2}=81 \%$ ) in comparison with the control group. However, the above analysis showed unacceptable heterogeneity $\left(\mathrm{I}^{2}=81 \%\right)$. Therefore, based on the sensitivity analysis, we found and eliminated the study [19] that caused high heterogeneity (Figure 7a). After re-analysis, which accounted for the exclusion of the above study, we noticed highly significant lowering of DBP in the Spirulina group (MD: -7.02 $\mathrm{mmHg}$, CI: -8.86 to $-5.18, \mathrm{I}^{2}=11 \%$ ) compared with the control group (Figure $7 \mathrm{~b}$ ).

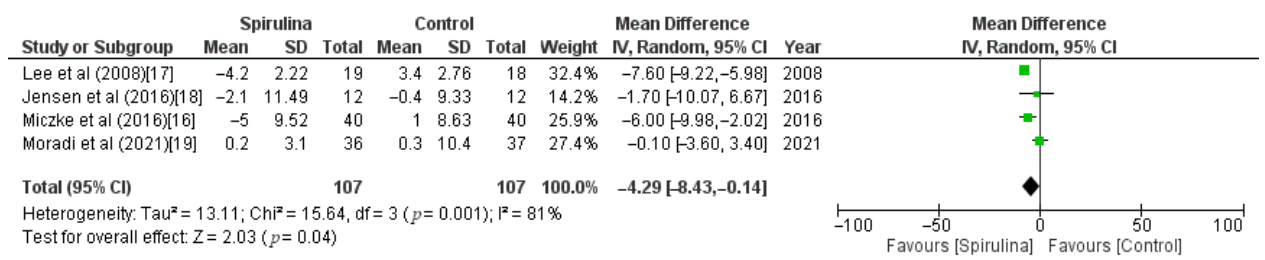

(a)

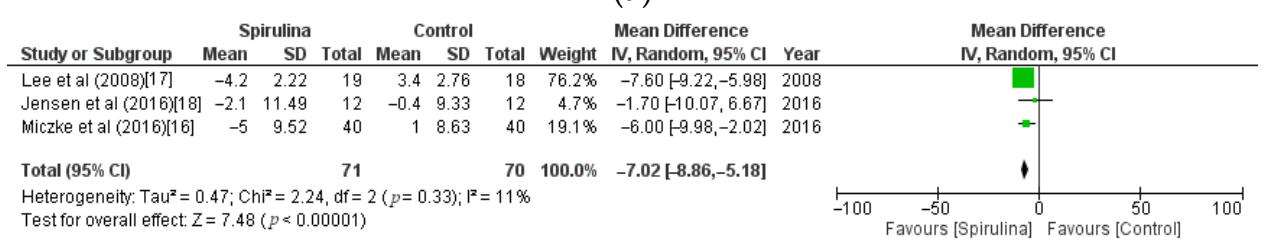

(b)

Figure 7. (a). Effect of Spirulina supplementation on systolic blood pressure (SBP) compared with the control group stratified by baseline blood pressure [16-19]. (b). Effect of Spirulina supplementation on diastolic blood pressure (DBP) compared with the control group-studies causing high heterogeneity excluded [16-18].

\section{Discussion}

Arterial hypertension is one of the most common health problems in developed countries and is a risk factor for cardiovascular diseases. Numerous studies have shown the positive effect of certain nutrients and dietary interventions on high blood pressure levels [27]. Diet with natural fruits and vegetables containing antioxidants has a blood pressure-lowering effect [27]. According to recent studies, lycopene-carotenoid from tomatoes or such nutraceuticals as flavonoids contained in cacao, beetroot with nitrates, garlic, and fish oil, being a source of unsaturated fats, have the potential to improve blood pressure $[27,28]$.

In this paper, we present the results of a systematic review and meta-analysis which indicated Spirulina supplementation significant reduction of systolic and diastolic blood pressure. Our meta-analysis focuses on SBP and DBP parameters and not all components 
of metabolic syndrome, which makes the study comprehensible. Spirulina is a functional food that might have a beneficial effect on decreasing blood pressure. However, individual RCTs showed some different results regarding blood pressure values between themselves. Martínez-Sámano et al. showed a statistically significant decrease in systolic blood pressure after 12 weeks of Spirulina supplementation in a dose of $4.5 \mathrm{~g}$ per day $(p<0.05)$ and no statistically significant changes regarding the diastolic blood pressure [15]. Miczke et al. confirmed a hypotensive effect of Spirulina. Significant decreases in SBP and DBP were observed in the Spirulina group after three months of treatment with $2 \mathrm{~g}$ [16]. Administration of $8 \mathrm{~g}$ per day of Spirulina for 12 weeks showed a significant lowering effect on DBP $(p<0.021)$ and no significant effect on SBP in the study by Lee et al. [17]. Results of the study by Jensen et al. indicated that with a dose of $2.3 \mathrm{~g}$ there were no statistically significant differences between Spirulina and placebo groups regarding SBP and DBP at baseline or after 2 weeks. However, the consumption was associated with a mild reduction in DBP [18]. In contrast, Moradi et al. claimed that Spirulina taken $1 \mathrm{~g}$ per day by ulcerative colitis patients did not influence blood pressure values $(p>0.05)$ [19].

Discrepancies require further in-depth analyzes. Some other possible confounding factors in assessing the impact of Spirulina on SBP and DBP, for example, physical activity, diet, and smoking should be taken into consideration. These conflicting outcomes of the studies can depend on the supplementation of different doses of Spirulina in different periods of time. The fact that no significant hypotensive effect was seen after administration of $1 \mathrm{~g}$ of Spirulina might suggest the role of the appropriate dosage of the supplement to decrease blood pressure. It is worth mentioning that no significant changes in blood pressure parameters were noted in studies, in which the duration of Spirulina supplementation was below 12 weeks: 2 or 8 weeks, respectively $[18,19]$. Studies of 12 weeks of Spirulina administration showed a significant decrease in at least one component of blood pressure [15-17]. However, our subgroup analysis based on a dose of supplementation indicated that there was no significant difference between dose $\leq 2 \mathrm{~g}$ or $>2 \mathrm{~g}$, and subgroup analysis based on " $\geq 12$ weeks" or " $<12$ weeks" duration of Spirulina intake did not show any difference between subgroups. Meta-analysis results are evidence of greater importance than analysis of particular studies. It is worth highlighting that Spirulina supplementation resulted in greater SBP lowering in a subgroup of hypertensive patients compared with those with normal blood pressure. It suggests that patients with hypertension might reap greater benefits with Spirulina supplementation. Both dosage and the duration of supplementation require further studies.

Other non-randomized controlled studies assessing a relationship between Spirulina intake and blood pressure values showed that $4.5 \mathrm{~g}$ per day for 6 weeks had the positive effect on SBP and DBP reduction in a sample of overweight patients [29]. On the contrary, Mazopakis et al. found no significant changes in SBP and DBP after the intervention of $1 \mathrm{~g}$ of Spirulina per day for 12 weeks in a Cretan population [30,31].

The mechanism of lowering blood pressure by Spirulina is partially understood. It was supposed that the high content of potassium in Spirulina might have a lowering effect on blood pressure [17]. Phycocyanin, a blue pigment with antioxidant activity from Spirulina, decreases parameters of blood pressure by strenghtening the expression of endothelial nitric oxide synthase in the aorta after the stimulation of adiponectin [19,32]. Oxidative stress connected to endothelial damage, contributing to a decrease in nitric oxide synthase (NOs), and decreased vasoconstriction has been reported in hypertension [15]. In mice, the decameric peptide of Spirulina platensis decreases blood pressure levels through a PI3K (phosphoinositide-3-kinase)/AKT (serine/threonine kinase Akt)/eNOS (endothelial NO synthase) -dependent mechanism [33]. Martínez-Sámano et al. proved the antioxidative properties of Spirulina in SBP-they observed an increase in glutathione peroxidase (GPx) activity and oxidized glutathione (GSSG) concentrations $(p<0.05)$ [15]. Additionally, sVCAM-1, sE-selectin, and endothelin-1 levels-considered as markers of endothelial dysfunction were reduced [15]. Spirulina improves endothelial function by reducing arterial stiffness index (SI) [34]. Moreover, Spirulina contains natural angiotensin I converting 
enzyme inhibitor (ACEi) peptide. ACEi suppresses the synthesis of angiotensin II that induces the vasoconstriction of blood vessels and the release of aldosterone, resulting in blood pressure increase [34-36]. More studies should be performed to confirm these hypotheses and evaluate the exact mechanism of antihypertensive properties of the substance in humans.

Due to many complications of hypertension, intake of Spirulina with antioxidant and hypotensive activity might reduce blood pressure, which potentially reduces cardiovascular risk and prevents serious effects such as stroke or heart attack. Moreover, hypertension is frequently associated with diabetes mellitus and metabolic syndrome. Some studies revealed that Spirulina intake improved glucose and lipid metabolism, reduced oxidative stress, modulated appetite, so it can be considered as a therapeutic nutraceutical not only by reducing blood pressure [13,32]. According to our analysis, Spirulina may potentially reduce blood pressure among hypertensive patients. Supplementation of Spirulina products promoted as "superfoods" is more and more popular due to its health benefits, but recent studies revealed contamination of toxic substances-cyanotoxins, heavy metals, or polycyclic aromatic hydrocarbons (PAHs) [37,38]. Further research is needed, which doses and forms are the most effective and safe for patients. It is necessary to assess the safety profile of combination therapy consisting of Spirulina and pharmacotherapy.

The limitations of this meta-analysis were the small number of analyzed RCTs and the lack of possibility to assess publication bias. However, the greatest strength of this paper is the inclusion of two novel studies from 2018 and 2021 [15,19]. The studies were first included in a meta-analysis that broadened the analysis compared with the previous meta-analysis assessing the influence of Spirulina supplementation on a decrease of blood pressure. In the meta-analysis by Huang $\mathrm{H}$. et al. Spirulina supplements significantly lowered DBP (weighted mean differences $=-7.17 \mathrm{mmHg} ; 95 \% \mathrm{CI}$ : -8.57 to $-5.78 ; p=0.0001$; $\mathrm{I}^{2}=0 \%$ ), but not SBP (weighted mean differences $=-3.49 \mathrm{mmHg} ; 95 \% \mathrm{CI}:-7.19$ to 0.21 ; $p=0.06 ; \mathrm{I}^{2}=50 \%$ ) [39]. Differences in included studies might be a reason for different results for SBP compared with our meta-analysis. Yousefi et al. in a systematic review came to similar conclusions to our meta-analysis that additional studies with greater sample sizes and extended durations are needed to establish the hypotensive effect of Spirulina [40].

\section{Conclusions}

In summary, the results of the current meta-analysis indicated that Spirulina supplementation might have a supportive effect on the prevention and treatment of hypertension. Spirulina intake had beneficial hypotensive properties, particularly in patients with hypertension compared to those with normal blood pressure. Spirulina should be further used as a nutraceutical food supplement due to its pro-health properties. More RTCs with different dosages and the duration of Spirulina administration are recommended to be conducted to clarify the effect of Spirulina on systolic and diastolic blood pressure and to determine its clinical relevance in hypertension management.

Author Contributions: Conceptualization, P.M.; methodology, P.M. and G.R.; software, P.M.; validation, P.M., G.R. and M.M.; formal analysis, G.R., M.M. and H.P.-S.; investigation, G.R. and M.M.; resources, P.M.; data curation, P.M., A.S.; writing-original draft preparation, P.M. and G.R.; writing-review and editing, P.M., G.R., M.M.; visualization, P.M.; supervision, H.P.-S., A.S.; project administration, H.P.-S., A.S.; funding acquisition, H.P.-S., A.S. All authors have read and agreed to the published version of the manuscript.

Funding: This research received no external funding.

Institutional Review Board Statement: Not applicable.

Informed Consent Statement: Not applicable.

Data Availability Statement: Not applicable.

Conflicts of Interest: The authors declare no conflict of interest. 


\section{References}

1. Salkic, S.; Ljuca, F.; Batic-Mujanovic, O.; Brkic, S.; Mesic, D.; Mustafic, S. The Frequency of Hypertension Crises in the Emergency Medical Service Department in Tuzla. Med. Arch. 2013, 67, 393-396. [CrossRef] [PubMed]

2. Wermelt, J.A.; Schunkert, H. Management der arteriellen Hypertonie. Herz 2017, 42, 515-526. [CrossRef] [PubMed]

3. Sood, N.; Reinhart, K.M.; Baker, W.L. Combination therapy for the management of hypertension: A review of the evidence. Am. J. Health Pharm. 2010, 67, 885-894. [CrossRef]

4. Riva, N.; Lip, G.Y. Which is the Optimal Antihypertensive Combination in Different Diseases, a Renin- Angiotensin-aldosterone System Inhibitor with a Diuretic or with a Calcium Channel Blocker? Curr. Pharm. Des. 2013, 19, 3753-3765. [CrossRef]

5. Ardalani, H.; Moghadam, M.H.; Rahimi, R.; Soltani, J.; Mozayanimonfared, A.; Moradi, M.; Azizi, A. Sumac as a novel adjunctive treatment in hypertension: A randomized, double-blind, placebo-controlled clinical trial. RSC Adv. 2016, 6, 11507-11512. [CrossRef]

6. Buono, S.; Langellotti, A.L.; Martello, A.; Rinna, F.; Fogliano, V. Functional ingredients from microalgae. Food Funct. 2014, 5, 1669-1685. [CrossRef]

7. Christaki, E.; Florou-Paneri, P.; Bonos, E. Microalgae: A novel ingredient in nutrition. Int. J. Food Sci. Nutr. 2011, 62, 794-799. [CrossRef]

8. Finamore, A.; Palmery, M.; Bensehaila, S.; Peluso, I. Antioxidant, Immunomodulating, and Microbial-Modulating Activities of the Sustainable and EcofriendlySpirulina. Oxidative Med. Cell. Longev. 2017, 2017, 3247528. [CrossRef]

9. Deng, R.; Chow, T.-J. Hypolipidemic, Antioxidant, and Antiinflammatory Activities of Microalgae Spirulina. Cardiovasc. Ther. 2010, 28, e33-e45. [CrossRef]

10. Wu, Q.; Liu, L.; Miron, A.; Klímová, B.; Wan, D.; Kuča, K. The antioxidant, immunomodulatory, and anti-inflammatory activities of Spirulina: An overview. Arch. Toxicol. 2016, 90, 1817-1840. [CrossRef]

11. Gunes, S.; Tamburaci, S.; Dalay, M.C.; Gurhan, I.D. In vitro evaluation of Spirulina platensis extract incorporated skin cream with its wound healing and antioxidant activities. Pharm. Biol. 2017, 55, 1824-1832. [CrossRef]

12. Cho, J.A.; Baek, S.Y.; Cheong, S.H.; Kim, M.R. Spirulina Enhances Bone Modeling in Growing Male Rats by Regulating GrowthRelated Hormones. Nutrients 2020, 12, 1187. [CrossRef]

13. Serban, M.-C.; Sahebkar, A.; Dragan, S.; Stoichescu-Hogea, G.; Ursoniu, S.; Andrica, F.; Banach, M. A systematic review and meta-analysis of the impact of Spirulina supplementation on plasma lipid concentrations. Clin. Nutr. 2016, 35, 842-851. [CrossRef] [PubMed]

14. Masuda, K.; Chitundu, M. Multiple micronutrient supplementation using Spirulina platensis and infant growth, morbidity, and motor development: Evidence from a randomized trial in Zambia. PLoS ONE 2019, 14, e0211693. [CrossRef] [PubMed]

15. Martínez-Sámano, J.; De Oca, A.T.-M.; Luqueño-Bocardo, O.I.; Torres-Durán, P.V.; Juárez-Oropeza, M.A. Spirulina maxima Decreases Endothelial Damage and Oxidative Stress Indicators in Patients with Systemic Arterial Hypertension: Results from Exploratory Controlled Clinical Trial. Mar. Drugs 2018, 16, 496. [CrossRef]

16. Miczke, A.; Szulinska, M.; Hansdorfer-Korzon, R.; Kręgielska-Narożna, M.; Suliburska, J.; Walkowiak, J.; Bogdański, P. Effects of spirulina consumption on body weight, blood pressure, and endothelial function in overweight hypertensive Caucasians: A double-blind, placebo-controlled, randomized trial. Eur. Rev. Med. Pharmacol. Sci. 2016, 20, 150-156.

17. Lee, E.H.; Park, J.-E.; Choi, Y.-J.; Huh, K.-B.; Kim, W.-Y. A randomized study to establish the effects of spirulina in type 2 diabetes mellitus patients. Nutr. Res. Pract. 2008, 2, 295-300. [CrossRef] [PubMed]

18. Jensen, G.S.; Drapeau, C.; Lenninger, M.; Benson, K.F. Clinical Safety of a High Dose of Phycocyanin-Enriched Aqueous Extract from Arthrospira (Spirulina) platensis: Results from a Randomized, Double-Blind, Placebo-Controlled Study with a Focus on Anticoagulant Activity and Platelet Activation. J. Med. Food 2016, 19, 645-653. [CrossRef]

19. Moradi, S.; Zobeiri, M.; Feizi, A.; Clark, C.C.T.; Entezari, M.H. The effects of spirulina (Arthrospira platensis) supplementation on anthropometric indices, blood pressure, sleep quality, mental health, fatigue status and quality of life in patients with ulcerative colitis: A randomised, double-blinded, placebo-controlled trial. Int. J. Clin. Pract. 2021, e14472. [CrossRef]

20. Moher, D.; Shamseer, L.; Clarke, M.; Ghersi, D.; Liberati, A.; Petticrew, M.; Shekelle, P.; Stewart, L.A.; PRISMA-P Group. Preferred reporting items for systematic review and meta-analysis protocols (PRISMA-P) 2015 statement. Syst. Rev. 2015, 4, 1. [CrossRef]

21. Jadad, A.R.; Moore, R.A.; Carroll, D.; Jenkinson, C.; Reynolds, D.J.; Gavaghan, D.J.; McQuay, H.J. Assessing the quality of reports of randomized clinical trials: Is blinding necessary? Control. Clin. Trials 1996, 17, 1-12. [CrossRef]

22. Moher, D.; Cook, D.J.; Jadad, A.R.; Tugwell, P.; Jones, A.; Pham, B.; Klassen, T.P. Assessing the quality of reports of randomised trials: Implications for the conduct of meta-analyses. Health Technol. Assess 1999, 3, 98. [CrossRef]

23. DerSimonian, R.; Laird, N. Meta-analysis in clinical trials. Control. Clin. Trials 1986, 7, 177-188. [CrossRef]

24. Jafari, T.; Fallah, A.A.; Barani, A. Effects of vitamin D on serum lipid profile in patients with type 2 diabetes: A meta-analysis of randomized controlled trials. Clin. Nutr. 2016, 35, 1259-1268. [CrossRef]

25. Jafari, T.; Feizi, A.; Askari, G.; Fallah, A.A. Parenteral immunonutrition in patients with acute pancreatitis: A systematic review and meta-analysis. Clin. Nutr. 2015, 34, 35-43. [CrossRef]

26. Higgins, J.P.T.; Deeks, J.; Altman, D. Special topics in statistics. In Cochrane Handbook for Systematic Reviews of Interventions; Higgins, J.P.T., Green, S., Eds.; Version 5.1.0 [Updated March 2011]; The Cochrane Collaboration: London, UK, 2011. Available online: www.handbook.cochrane.org (accessed on 10 July 2021). 
27. Rattanavipanon, W.; Nithiphongwarakul, C.; Sirisuwansith, P.; Chaiyasothi, T.; Thakkinstian, A.; Nathisuwan, S.; Pathomwichaiwat, T. Effect of tomato, lycopene and related products on blood pressure: A systematic review and network meta-analysis. Phytomedicine 2021, 88, 153512. [CrossRef]

28. Fantin, F.; Macchi, F.; Giani, A.; Bissoli, L. The Importance of Nutrition in Hypertension. Nutrients 2019, 11, 2542. [CrossRef] [PubMed]

29. Torres-Duran, P.V.; Ferreira-Hermosillo, A.; Juarez-Oropeza, M.A. Antihyperlipemic and antihypertensive effects of Spirulina maxima in an open sample of mexican population: A preliminary report. Lipids Health Dis. 2007, 6, 33-38. [CrossRef]

30. Mazokopakis, E.E.; Papadomanolaki, M.G.; Fousteris, A.A.; Kotsiris, D.A.; Lampadakis, I.M.; Ganotakis, E. The hepatoprotective and hypolipidemic effects of Spirulina (Arthrospira platensis) supplementation in a Cretan population with non-alcoholic fatty liver disease: A prospective pilot study. Ann. Gastroenterol. 2014, 27, 387-394.

31. Mazokopakis, E.; Starakis, I.K.; Papadomanolaki, M.G.; Mavroeidi, N.G.; Ganotakis, E. The hypolipidaemic effects of Spirulina (Arthrospira platensis) supplementation in a Cretan population: A prospective study. J. Sci. Food Agric. 2014, 94, 432-437. [CrossRef] [PubMed]

32. Bobescu, E.; Bălan, A.; Moga, M.A.; Teodorescu, A.; Mitrică, M.; Dima, L. Are There Any Beneficial Effects of Spirulina Supplementation for Metabolic Syndrome Components in Postmenopausal Women? Mar. Drugs 2020, 18, 651. [CrossRef]

33. Carrizzo, A.; Conte, G.M.; Sommella, E.; Damato, A.; Ambrosio, M.; Sala, M.; Scala, M.C.; Aquino, R.P.; De Lucia, M.; Madonna, M.; et al. Novel Potent Decameric Peptide of Spirulina platensis Reduces Blood Pressure Levels Through a PI3K/AKT/eNOSDependent Mechanism. Hypertension 2019, 73, 449-457. [CrossRef]

34. Szulinska, M.; Gibas-Dorna, M.; Miller-Kasprzak, E.; Suliburska, J.; Miczke, A.; Walczak-Gałezewska, M.; Stelmach-Mardas, M.; Walkowiak, J.; Bogdanski, P. Spirulina maxima improves insulin sensitivity, lipid profile, and total antioxidant status in obese patients with well-treated hypertension: A randomized double-blind placebo-controlled study. Eur. Rev. Med. Pharmacol. Sci. 2017, 21, 2473-2481. [PubMed]

35. Anekthanakul, K.; Senachak, J.; Hongsthong, A.; Charoonratana, T.; Ruengjitchatchawalya, M. Natural ACE inhibitory peptides discovery from Spirulina (Arthrospira platensis) strain C1. Peptides 2019, 118, 170107. [CrossRef]

36. Wang, K.; Luo, Q.; Hong, H.; Liu, H.; Luo, Y. Novel antioxidant and ACE inhibitory peptide identified from Arthrospira platensis protein and stability against thermal/pH treatments and simulated gastrointestinal digestion. Food Res. Int. 2021, 139, 109908. [CrossRef]

37. Grosshagauer, S.; Kraemer, K.; Somoza, V. The True Value of Spirulina. J. Agric. Food Chem. 2020, 68, 4109-4115. [CrossRef] [PubMed]

38. Papadimitriou, T.; Kormas, K.; Vardaka, E. Cyanotoxin contamination in commercial Spirulina food supplements. J. Consum. Prot. Food Saf. 2021, 16, 227-235. [CrossRef]

39. Huang, H.; Liao, D.; Pu, R.; Cui, Y. Quantifying the effects of spirulina supplementation on plasma lipid and glucose concentrations, body weight, and blood pressure. Diabetes Metab. Syndr. Obes. Targets Ther. 2018, 11, 729-742. [CrossRef]

40. Yousefi, R.; Saidpour, A.; Mottaghi, A. The effects of Spirulina supplementation on metabolic syndrome components, its liver manifestation and related inflammatory markers: A systematic review. Complement. Ther. Med. 2019, 42, 137-144. [CrossRef] 